\section{Factors associated with sexual initiation and condom use among adolescents on Santiago Island, Cape Verde, West Africa}

\author{
Fatores associados ao início da vida sexual e o uso \\ de preservativo entre adolescentes da llha de \\ Santiago, Cabo Verde, África Ocidental
}

\section{Faculdade de Saúde Pública, Universidade de São Paulo, São Paulo, Brasil. \\ Correspondence \\ N. Schor \\ Departamento de Saúde Materno-Infantil, Faculdade de Saúde Pública Universidade de São Paulo. Av. Dr. Arnaldo 715 2 o andar, sala 218 São Paulo, SP 01246-904, Brasil. neschor@usp.br}

\begin{abstract}
The current study focuses on factors associated with sexual initiation and condom use among teenagers on Santiago Island, Cape Verde, according to gender. This was a representative, probabilistic sample of 13-to-17-year-olds $(n=768)$ attending public secondary schools on Santiago Island in 2007. Associations were tested by test of proportion, Pearson's chi-square, or Fisher's exact test and logistic regression. Factors related to sexual initiation among boys were: age over 14 years, Catholic religion, and alcohol consumption. For girls, the factors included: > 9 years of schooling and involvement in an affective-sexual relationship. Unlike other Sub-Saharan countries, this study showed a high prevalence of condom use during initial sexual activity. Adolescents are able to safely begin sexually active life if they have access to information, sex education, and other STD prevention and contraceptive methods. This study provides insights on the development of policies to reduce the vulnerability of the young population to STD/AIDS and the limits and challenges related to the promotion of condom use and sex education, focusing on unequal gender relations.
\end{abstract}

Sexual and Reproductive Health; Condoms; Adolescent
Carlos Mendes Tavares 1

Néia Schor 1

Ivan França Junior 1

Simone Grilo Diniz 1

\section{Introduction}

Sexual activities during adolescence have been characterized as dynamic and constantly changing, with potential impact on reproductive life and a $2.8 \%$ increase in fertility rates in the 15 to-19-year age group observed in Cape Verde from 1990 to 2000 1. Another important health dimension relates to the increased susceptibility to HIV transmission when such activities are unprotected or performed under coercion.

One of the indicators for sexual activity most widely used in the literature has been age at first sexual intercourse 2,3.

Nearly worldwide, sexual initiation has occurred in adolescence at increasingly younger ages 3,4 . Differences in sexual initiation between males and females are expressed as a gender issue, i.e., there still appears to be social pressure for earlier sexual activity by males, so as to differentiate themselves from females. Meanwhile, traditional gender relations assume that young people delay their sexual initiation until marriage. The literature points to various factors associated with earlier sexual initiation, including: age, gender, religion, schooling, color, work status, media exposure, family structure, and parent-child relationship 5. Earlier sexual initiation per se is not a problem, but it may indicate situations in which young people have initiated their sex life without protection and/or in the face of violence 6,7 . 
Few studies have explored factors associated with sexual initiation and gender differences in Sub-Saharan African countries, specifically Cape Verde.

This article analyzed factors associated with sexual initiation in adolescents on Santiago Island, Cape Verde, according to gender.

\section{Methodology}

Cape Verde is an archipelago consisting of nine inhabited islands located in the Atlantic Ocean, occupying some $4,000 \mathrm{~km}^{2}$. This study was conducted on Santiago Island, with the country's largest area $\left(991 \mathrm{~km}^{2}\right)$ and population $(234,940$ inhabitants $-54 \%$ of the total) 8,9

This was a cross-sectional study of adolescents enrolled in public secondary schools, conducted from January to March 2007. On Santiago Island, secondary school lasts for six years and is organized in three cycles lasting two years each.

The inclusion criterion for the study was adolescents from 13 to 17 years of age, since they are old enough to begin sexual activity and fit the chronological definition of adolescent according to the World Health Organization (WHO) 10.

This group corresponds to $74 \%$ of the adolescents enrolled in secondary school in Cape Verde 11 . The enrollment rate is not similar on all the islands, and is higher on Santiago Island due to its more privileged socioeconomic situation.

The 11-to-12-year-old population was not included in the study, because it was felt that they would be too embarrassed to answer the questionnaire. Only public schools were studied, because there were no records for 13-to-17year-olds enrolled in private secondary schools 12, perhaps because the country's public teaching institutions are free and provide better education.

Eligibility criteria for participating in the study were: adolescents attending secondary school on Santiago Island; age from 13 to 17 years; and being regularly enrolled in public secondary school.

A two-stage probabilistic sampling technique was used: stage 1 (sampling by strata) - stratification by municipality, with a draw of schools by municipality; stage 2 (cluster sampling) - division by schools, with a draw of classes (in all the selected schools) by school year, and a subsequent list of all the students with target characteristics in each selected class.

The sample size was calculated based on the percentage of sexually active adolescents, estimated at $83.6 \%$, with an assumed sampling error of $3 \%$, and a $95 \%$ confidence interval, in a popu- lation of 25,618 schoolchildren. The estimated sample size was 576 adolescents, subsequently corrected for a finite population, to which we added $28 \%$, considering the possibility of losses.

The final planned sample was 768 adolescents, divided equally by gender. Eight public schools were selected among the total of 16 on the island.

After the selection, a collective explanation was provided to the participants in each of the eight schools on the research objectives, procedures, and the voluntary nature of their participation, as well as a guarantee of the confidentiality of individual information, that is, that the information requested in the research would be confidential and would only be used for scientific purposes. Parents or guardians were asked to sign a free and informed consent form.

All the selected adolescents were dismissed from their classes in order to answer the selfapplied questionnaire in a single classroom, for 50 minutes. The research was approved by the Institutional Review Board of the School of Public Health, University of São Paulo (FSP/USP), protocol no. 1,480 . There were no refusals to participate in the study.

The dependent variable in the study was sexual initiation. The following were independent variables: socio-demographic - age, gender, schooling, affective/sexual partner, religion, church attendance, media exposure (having a TV and/or radio), number of persons per household, age at menarche, and hometown - and those related to smoking and alcohol consumption.

The database was constructed using CSPro 6.0 (http://www.cspro.org/cspro/start.cfm), with double keying-in. During the study's analytical phase, the database was converted to STATA 10 (Stata Corp., College Station, USA).

The Anderson-Darling test was used to test for normal distribution of the variables. The descriptive analysis was presented by means of proportions, means, and standard deviations. Hypotheses for proportions were tested with the chi-square, Fisher's exact, and proportion test. Odds ratios were calculated by logistic regression. Significance was set at $5 \%$.

The data were analyzed hierarchically: the first level consisted of the socio-demographic variables and the second included smoking and alcohol consumption.

All the variables with $\mathrm{p} \leq 0.20$ in the logistic regression or chi-square or Pearson or Fisher's exact test were included in the hierarchical model. In the final model, all the variables were maintained whose association with sexual initiation remained at $\leq 0.05$, controlling and not controlling for age. To analyze the factors, it was 
assumed that age would be an effect-modifying variable in the logistic regression models. Two models were analyzed: model A, with the independent variables not controlled for age, and model B, when controlled for age.

\section{Results}

The study sample included 768 adolescents. Mean age was 15.5 years ( $\mathrm{SD}=1.4)$, and the majority $(73.7 \%)$ were over 14 . Among the subjects, $33.9 \%$ (261) belonged to the first two-year series of secondary school, and 33\% (254) and 32.9\% (253), respectively, to the second and third twoyear series.

There was a difference in the percentage of responses according to gender, concerning knowledge about the use of contraceptive methods during sexual initiation. Meanwhile, more schooling was associated with having used some contraceptive method.

The adolescents showed a high level of information on the most familiar contraceptive methods $(93 \%$ knew some type of contraceptive method before their first sexual intercourse).

A high rate $(84.72 \%)$ reported having used a condom in their first sexual intercourse. Of these, $78 \%$ stated having used condoms to avoid unplanned pregnancy, $67 \%$ to avoid unplanned pregnancy and STDs, and 58\% to avoid STDs, including AIDS.

Catholic adolescents represented $84 \%$ of the participants, while non-Catholics and those not reporting any religion represented $5 \%$ and $11 \%$, respectively.

Mean number of individuals per household was $6.3(\mathrm{SD}=2.6)$. Mean age at menarche was 13.26 years $(\mathrm{SD}=1.1)$. History of pregnancy was reported by $12 \%$ of the girls, of whom more than two-thirds ( $86 \%$ ) had children by age 17 and $14 \%$ between 15 and 16 years of age. Table 1 shows the age distribution and number and percentage of adolescents for each age, by gender.

Table 2 shows the results of the distribution of adolescents according to sexual initiation, potentially associated variables, and gender. Among boys, the highest rates of sexual initiation were associated with Catholic religion, alcohol consumption, age over 14 years, and more than nine years of schooling.

The data in Table 2 were similar to the estimates from the logistic regression model (Table 3).

Table 4 provides the estimates from the logistic regression model for sexual initiation, according to gender, without considering age in model A and including age in model B. In model A, more than nine years of schooling, having an affective/ sexual partner, and Catholic religion were directly associated with sexual initiation. The first two factors were associated with female gender and the latter with male gender. Alcohol consumption was positively associated with sexual initiation in both models.

The same factors were associated in models $\mathrm{A}$ and $\mathrm{B}$. Thus, age was not an effect-modifying variable.

For girls, positive associations were observed with the following factors: more than nine years of schooling and having an affective/sexual partner (Table 5).

Meanwhile, the factors associated with sexual initiation in boys were: age greater than 14 years, Catholic religion, and alcohol consumption.

\section{Discussion}

This study is one of the few in Sub-Saharan Africa, particularly in Cape Verde, that estimated factors associated with sexual initiation according

Absolute and proportional age distribution of adolescents by gender. Santiago Island, Cape Verde, 2007.

\begin{tabular}{|c|c|c|c|c|}
\hline \multirow[t]{2}{*}{ Age (years) } & \multicolumn{2}{|c|}{ Female } & \multicolumn{2}{|c|}{ Male } \\
\hline & $n$ & $\%$ & $\mathrm{n}$ & $\%$ \\
\hline 13 & 57 & 14.84 & 43 & 11.20 \\
\hline 14 & 53 & 13.80 & 49 & 12.76 \\
\hline 15 & 70 & 18.23 & 69 & 17.94 \\
\hline 16 & 71 & 18.49 & 72 & 18.75 \\
\hline 17 & 133 & 34.64 & 151 & 39.32 \\
\hline Total & 384 & 100.00 & 384 & 100.00 \\
\hline
\end{tabular}


Distribution of adolescents according to sexual initiation, possible significant variables, and gender. Santiago Island, Cape Verde, 2007.

\begin{tabular}{|c|c|c|c|c|c|c|c|c|c|c|}
\hline \multirow[t]{4}{*}{ Independent variables } & \multicolumn{10}{|c|}{ Dependent variable: sexual initiation } \\
\hline & \multicolumn{5}{|c|}{ Female } & \multicolumn{5}{|c|}{ Male } \\
\hline & \multicolumn{2}{|c|}{ Yes } & \multicolumn{2}{|c|}{ No } & \multirow[t]{2}{*}{$p$-value } & \multicolumn{2}{|c|}{ Yes } & \multicolumn{2}{|c|}{ No } & \multirow[t]{2}{*}{ p-value } \\
\hline & $\mathrm{n}$ & $\%$ & $\mathrm{n}$ & $\%$ & & $\mathrm{n}$ & $\%$ & $\mathrm{n}$ & $\%$ & \\
\hline \multicolumn{11}{|l|}{ Age bracket (years) } \\
\hline$\leq 14$ & 16 & 14.55 & 94 & 85.45 & 0.000 * & 48 & 52.17 & 44 & 47.83 & 0.002 * \\
\hline$>14$ & 100 & 36.50 & 174 & 63.50 & & 204 & 69.86 & 88 & 30.14 & \\
\hline Total & 116 & 30.21 & 268 & 69.79 & & 252 & 65.63 & 132 & 34.38 & \\
\hline Mean age at sexual initiation & \multicolumn{4}{|c|}{$15(\mathrm{SD}=1.64)$} & \multicolumn{6}{|c|}{$14(\mathrm{SD}=2.0)$} \\
\hline \multicolumn{11}{|l|}{ Schooling (years) } \\
\hline$\leq 9$ & 39 & 20.10 & 155 & 79.90 & 0.000 * & - & - & - & - & - \\
\hline$>9$ & 76 & 40.21 & 113 & 59.79 & & - & - & - & - & \\
\hline Total & 115 & 30.03 & 268 & 69.97 & & - & - & - & - & \\
\hline $\begin{array}{l}\text { Mean years of schooling at sexual } \\
\text { initiation }\end{array}$ & \multicolumn{4}{|c|}{$10.1(\mathrm{SD}=1.68)$} & \multicolumn{6}{|c|}{$9.6(\mathrm{SD}=1.67)$} \\
\hline \multicolumn{11}{|l|}{ Partner } \\
\hline With ** & 51 & 48.57 & 54 & 51.43 & 0.000 * & 57 & 76.00 & 18 & 24.00 & 0.051 \\
\hline Without $* \star \star$ & 64 & 23.53 & 208 & 76.47 & & 191 & 64.09 & 107 & 35.91 & \\
\hline Total & 115 & 30.50 & 262 & 69.50 & & 248 & 66.49 & 125 & 35.51 & \\
\hline \multicolumn{11}{|l|}{ Religion \# } \\
\hline Catholic & - & - & - & - & - & 204 & 67.11 & 100 & 32.89 & 0.039 * \\
\hline Others \#\# & - & - & - & - & & 10 & 45.45 & 12 & 54.55 & \\
\hline Total & - & - & - & - & & 214 & 65.64 & 112 & 34.36 & \\
\hline \multicolumn{11}{|l|}{ Radio } \\
\hline Yes & - & - & - & - & - & 229 & 67.16 & 112 & 32.84 & 0.075 \\
\hline No & - & - & - & - & & 23 & 53.49 & 20 & 46.51 & \\
\hline Total & - & - & - & - & & 252 & 65.63 & 132 & 34.38 & \\
\hline \multicolumn{11}{|l|}{ Age at menarche (years) } \\
\hline$\leq 13$ & 68 & 38.20 & 110 & 61.80 & 0.068 & - & - & - & - & - \\
\hline$>13$ & 37 & 28.24 & 94 & 71.76 & & - & - & - & - & \\
\hline Total & 105 & 33.98 & 204 & 66.02 & & - & - & - & - & \\
\hline \multicolumn{11}{|l|}{ Home town } \\
\hline Tarrafal & 11 & 23.40 & 36 & 76.60 & 0.079 & - & - & - & - & - \\
\hline Assomada & 12 & 23.08 & 40 & 76.92 & & - & - & - & - & \\
\hline Santa Cruz & 15 & 30.61 & 34 & 69.39 & & - & - & - & - & \\
\hline Praia & 49 & 34.27 & 94 & 65.73 & & - & - & - & - & \\
\hline São Domingos & 19 & 44.19 & 24 & 55.81 & & - & - & - & - & \\
\hline São Miguel & 10 & 20.00 & 40 & 80.00 & & - & - & - & - & \\
\hline Total & 116 & 30.21 & 268 & 69.79 & & - & - & - & - & \\
\hline
\end{tabular}

(continues) 


\begin{tabular}{|c|c|c|c|c|c|c|c|c|c|c|}
\hline \multirow[t]{4}{*}{ Independent variables } & \multicolumn{10}{|c|}{ Dependent variable: sexual initiation } \\
\hline & \multicolumn{5}{|c|}{ Female } & \multicolumn{5}{|c|}{ Male } \\
\hline & \multicolumn{2}{|c|}{ Yes } & \multicolumn{2}{|c|}{ No } & \multirow[t]{2}{*}{$\mathrm{p}$-value } & \multicolumn{2}{|c|}{ Yes } & \multicolumn{2}{|c|}{ No } & \multirow[t]{2}{*}{ p-value } \\
\hline & $\mathrm{n}$ & $\%$ & $\mathrm{n}$ & $\%$ & & $\mathrm{n}$ & $\%$ & $\mathrm{n}$ & $\%$ & \\
\hline \multicolumn{11}{|l|}{ Alcohol consumption } \\
\hline Yes & 12 & 48.00 & 13 & 52.00 & $0.046^{*}$ & 46 & 83.64 & 9 & 16.36 & 0.002 * \\
\hline No & 104 & 29.05 & 254 & 70.95 & & 206 & 62.61 & 123 & 37.39 & \\
\hline Total & 116 & 30.29 & 267 & 69.71 & & 252 & 65.63 & 132 & 34.38 & \\
\hline \multicolumn{11}{|l|}{ SD: standard deviation. } \\
\hline \multicolumn{11}{|c|}{${ }^{*} \mathrm{p}<0.005$ according to chi-square or Fisher's exact test; } \\
\hline \multirow{3}{*}{\multicolumn{11}{|c|}{$\begin{array}{l}\text { ** In addition to "with partner" (the largest number), this category includes other situations, like those cohabiting in a consensual common-law union; } \\
\text { ** Only includes single individuals. Excludes data referring to separated individuals or other non-marital situations, because the sample is not statistically } \\
\text { significant, i.e., the expected value is less than 5; }\end{array}$}} \\
\hline & & & & & & & & & & \\
\hline & & & & & & & & & & \\
\hline \multirow{2}{*}{\multicolumn{11}{|c|}{$\begin{array}{l}\text { \# Have no religion, but believe in God; those that did not believe in God were not included, since the expected value was less than } 5 \text {; } \\
\text { \#\# Include Evangelical, Spiritist, and another unspecified church. }\end{array}$}} \\
\hline & & & & & & & & & & \\
\hline \multicolumn{11}{|c|}{ Note: (a) The co-variables that did not present $p<20 \%$ in the univariate analysis were not shown in this table; they are: smoking, religious attendance, having } \\
\hline
\end{tabular}

to gender. On Santiago Island, in 1998, mean age at sexual initiation for adolescents from 15 to 19 years of age was $15.8(\mathrm{SD}=1.2$ ) for girls and 15.2 ( $\mathrm{SD}=6.0$ ) for boys 8 . Another study, in 2005, showed a mean age of 15.0 years $(S D=3.2)$ for females and $13.1(\mathrm{SD}=5.0)$ for males 3 .

In Cape Verde, as in various other countries of the world, sexual initiation has occurred at increasingly younger ages 4,12 . The sexual initiation of male adolescents still occurs earlier than that of females, corresponding to the logic of gender relations ${ }^{13}$. Discussion on differences in sexual initiation between males and females are based on differences in family and social attitudes and expectations in relation to female and male conduct towards sexuality, i.e., boys appear to feel more stimulated to begin their sex life independently of marriage, while girls feel that it clashes with social expectations 14 .

Other studies in large Brazilian cities 2,15 indicate that male initiation precedes that of females, a phenomenon widely observed in Latin America, in part of Southeast Asia, and in European countries with a Latin culture 4 . However, in Nordic countries like Denmark, girls begin sexual experience earlier than boys ${ }^{4}$. The results of the current study do not corroborate the data from the report by the Cape Verde Ministry of Health 12 , according to which sexual life is beginning earlier in adolescents and mostly without adequate information. The current study's results show that although initiation has been early, adolescents report being well informed.
This difference in sexual initiation between girls and boys on the island can be understood more easily as a gender issue, and not one of biological sex, whereby males are encouraged to engage in an active sexual life at younger ages, while women are discouraged or even forbidden from engaging in sex before marriage. One out of four male adolescents had their first sexual intercourse at 12 years of age or less. In girls, this same percentage corresponded to an older age, 14 years or more. Mean age at sexual initiation for boys and girls was, respectively, $14(\mathrm{SD}=2.0)$ and $15(\mathrm{SD}=1.64)$, and the proportions of sexually initiated male and female adolescents were very different, $65.6 \%$ (252) and $30.2 \%$ (116), respectively, thus reinforcing the hypothesis of other studies 10,16 that male gender can be a factor associated with sexual initiation.

In the current study, the vast majority $(84.72 \%)$ of adolescents reported having used condoms in their first sexual intercourse. This high prevalence of condom use is even higher than in countries with what is considered high condom use, like Brazil. According to a recent study on prevalence of condom use in first sexual intercourse among Brazilian adolescents in 2005 was $68.3 \%$ and $62.5 \%$, respectively, for boys and girls 17 .

Thus, prevalence of condom use in the current study was very different from that of other Sub-Saharan African countries, where use of contraceptive methods by adolescents is generally low. The high proportion of condom use is typical of a generation that began sexual activity 
Estimates from the logistic regression model for sexual initiation, by gender, considering the independent response variable with each study co-variable. Santiago Island, Cape Verde, 2007.

\begin{tabular}{|c|c|c|c|c|}
\hline \multirow[t]{3}{*}{ Independent variables } & \multicolumn{4}{|c|}{ Dependent variable: sexual initiation } \\
\hline & \multicolumn{2}{|c|}{ Female } & \multicolumn{2}{|c|}{ Male } \\
\hline & OR $(95 \% \mathrm{Cl})$ & p-value & OR $(95 \% \mathrm{Cl})$ & $\mathrm{p}$-value \\
\hline \multicolumn{5}{|l|}{ Age bracket (years) } \\
\hline \multicolumn{5}{|l|}{$\leq 14$ (reference) } \\
\hline$>14$ & $3.38(1.88 ; 6.06)$ & $0.000 *$ & $2.13(1.32 ; 3.43)$ & 0.002 * \\
\hline \multicolumn{5}{|l|}{ Schooling (years) } \\
\hline \multicolumn{5}{|l|}{$\leq 9$ (reference) } \\
\hline$>9$ & $2.67(1.69 ; 4.22)$ & $0.000 *$ & - & - \\
\hline \multicolumn{5}{|l|}{ Partner } \\
\hline With & $3.07(1.91 ; 4.93)$ & $0.000 *$ & $1.77(0.99 ; 3.17)$ & 0.053 \\
\hline \multicolumn{5}{|l|}{ Without (reference) } \\
\hline \multicolumn{5}{|l|}{ Religion } \\
\hline Catholic & - & - & $2.45(1.02 ; 5.86)$ & 0.044 * \\
\hline \multicolumn{5}{|l|}{ Others (reference) } \\
\hline \multicolumn{5}{|l|}{ Radio } \\
\hline Yes & - & - & $1.78(0.94 ; 3.37)$ & 0.078 \\
\hline \multicolumn{5}{|l|}{ No (reference) } \\
\hline \multicolumn{5}{|l|}{ Age at menarche (years) } \\
\hline \multicolumn{5}{|l|}{$\leq 13$ (reference) } \\
\hline$>13$ & $0.64(0.39 ; 1.04)$ & 0.069 & - & - \\
\hline \multicolumn{5}{|l|}{ Alcohol consumption } \\
\hline Yes & $2.25(0.99 ; 5.10)$ & 0.051 & $3.05(1.44 ; 6.45)$ & 0.003 * \\
\hline
\end{tabular}

OR: odds ratio; $95 \% \mathrm{Cl}$ : $95 \%$ confidence interval.

${ }^{*} p<0.005$ in the univariate logistic regression.

Notes: (a) The co-variables that did not present $\mathrm{p}<20 \%$ in the univariate analysis were not shown in this table; they are: smoking, religious attendance, having a television set, persons per household, and hometown. (b) The symbol (-) means cases with co-variables greater than $p<20 \%$.

under the aegis of AIDS prevention campaigns and is especially relevant when considering that condom use during sexual initiation is positively associated with on-going use 17.

The European experience 18 has shown that consistent sex education since childhood - affirming the right to information and access to inputs, including condoms and contraceptives - dispenses with the discussion of postponing sexual initiation, which emerges as the consequence of knowledge acquired by youngsters.

In Cape Verde, in the last decade, there has been an increasing effort to implement public policies for sustained sex education for children, adolescents, and youth in the school setting, with the inclusion of a course for this purpose (per- sonal and social training) in secondary schools, resulting in the creation of the Project for the Introduction of Social Skills in STIs/HIV/AIDS in the primary and secondary school curricula. The project includes activities like talks, skits, and video debates on gender relations and contraceptive and condom use, having been assessed positively by students and teachers 19 . Likewise, young people's access to condoms has expanded in the health services. Despite their limits, such policies represent innovative initiatives that can make a major difference in the way adolescents deal with their sexual initiation in Cape Verde.

Meanwhile, in most other Sub-Saharan countries, fewer than $20 \%$ of married female adolescents use any contraceptive method, although 
Estimates from the multiple logistic regression model for sexual initiation according to gender for the complete model *. Santiago Island, Cape Verde, 2007.

\begin{tabular}{|c|c|c|c|c|c|c|c|c|}
\hline \multirow[t]{4}{*}{ Independent variables } & \multicolumn{8}{|c|}{ Dependent variable: sexual initiation } \\
\hline & \multicolumn{4}{|c|}{ Model A ** } & \multicolumn{4}{|c|}{ Model B *** } \\
\hline & \multicolumn{2}{|c|}{ Female } & \multicolumn{2}{|c|}{ Male } & \multicolumn{2}{|c|}{ Female } & \multicolumn{2}{|c|}{ Male } \\
\hline & $\begin{array}{c}\text { OR } \\
(95 \% \mathrm{Cl})\end{array}$ & $p$-value & $\begin{array}{c}\text { OR } \\
(95 \% \mathrm{Cl})\end{array}$ & p-value & $\begin{array}{c}\text { OR } \\
(95 \% \mathrm{Cl})\end{array}$ & $\mathrm{p}$-value & $\begin{array}{c}\text { OR } \\
(95 \% \mathrm{Cl})\end{array}$ & p-value \\
\hline \multicolumn{9}{|l|}{ Age bracket (years) } \\
\hline \multicolumn{9}{|l|}{$\leq 14$ (reference) } \\
\hline$>14$ & - & - & - & - & $\begin{array}{c}3.43 \\
(1.12 ; 10.49)\end{array}$ & 0.030 & $\begin{array}{c}2.33 \\
(1.15 ; 4.72)\end{array}$ & 0.019 \\
\hline \multicolumn{9}{|l|}{ Schooling (years) } \\
\hline \multicolumn{9}{|l|}{$\leq 9$ (reference) } \\
\hline$>9$ & $\begin{array}{c}2.92 \\
(1.63 ; 5.26)\end{array}$ & 0.000 & $\begin{array}{c}0.86 \\
(0.52 ; 1.42)\end{array}$ & 0.547 & $\begin{array}{c}1.95 \\
(1.01 ; 3.77)\end{array}$ & 0.046 & $\begin{array}{c}0.88 \\
(0.31 ; 1.07)\end{array}$ & 0.081 \\
\hline \multicolumn{9}{|l|}{ Partner } \\
\hline \multicolumn{9}{|l|}{ Without (reference) } \\
\hline With & $\begin{array}{c}3.08 \\
(1.74 ; 5.46)\end{array}$ & 0.000 & $\begin{array}{c}1.66 \\
(0.85 ; 3.23)\end{array}$ & 0.134 & $\begin{array}{c}2.91 \\
(1.63 ; 5.19)\end{array}$ & 0.000 & $\begin{array}{c}1.69 \\
(0.56 ; 3.32)\end{array}$ & 0.128 \\
\hline \multicolumn{9}{|l|}{ Religion } \\
\hline Catholic & $\begin{array}{c}0.56 \\
(0.13 ; 2.32)\end{array}$ & 0.423 & $\begin{array}{c}2.72 \\
(1.11 ; 6.70)\end{array}$ & 0.029 & $\begin{array}{c}0.49 \\
(0.11 ; 2.16)\end{array}$ & 0.347 & $\begin{array}{c}2.57 \\
(1.03 ; 6.40)\end{array}$ & 0.043 \\
\hline \multicolumn{9}{|l|}{ Others (reference) } \\
\hline \multicolumn{9}{|l|}{ Radio } \\
\hline \multicolumn{9}{|l|}{ No (reference) } \\
\hline Yes & $\begin{array}{c}0.65 \\
(0.29 ; 1.46)\end{array}$ & 0.292 & $\begin{array}{c}1.52 \\
(0.71 ; 3.28)\end{array}$ & 0.285 & $\begin{array}{c}0.59 \\
(0.25 ; 1.35)\end{array}$ & 0.209 & $\begin{array}{c}1.53 \\
(0.70 ; 3.34)\end{array}$ & 0.290 \\
\hline \multicolumn{9}{|l|}{ Age at menarche (years) } \\
\hline \multicolumn{9}{|l|}{$\leq 13$ (reference) } \\
\hline$>13$ & $\begin{array}{c}0.73 \\
(0.42 ; 1.27)\end{array}$ & 0.266 & - & - & $\begin{array}{c}0.66 \\
(0.38 ; 1.16)\end{array}$ & 0.148 & - & - \\
\hline \multicolumn{9}{|l|}{ Hometown } \\
\hline \multicolumn{9}{|l|}{ Others (reference) } \\
\hline Praia & $\begin{array}{c}1.26 \\
(0.72 ; 2.22)\end{array}$ & 0.582 & $\begin{array}{c}1.00 \\
(0.60 ; 1.68)\end{array}$ & 0.980 & $\begin{array}{c}1.30 \\
(0.74 ; 2.29)\end{array}$ & 0.368 & $\begin{array}{c}1.04 \\
(0.62 ; 1.74)\end{array}$ & 0.878 \\
\hline \multicolumn{9}{|l|}{ Alcohol consumption } \\
\hline Yes & $\begin{array}{c}1.21 \\
(0.43 ; 3.39)\end{array}$ & 0.481 & $\begin{array}{c}2.49 \\
(1.06 ; 5.82)\end{array}$ & 0.035 & $\begin{array}{c}1.17 \\
(0.42 ; 3.26\end{array}$ & 0.766 & $\begin{array}{c}2.39 \\
(1.02 ; 5.58)\end{array}$ & 0.045 \\
\hline No (reference) & & & & & & & & \\
\hline
\end{tabular}

OR: odds ratio; $95 \% \mathrm{Cl}$ : $95 \%$ confidence interval.

* Inclusion of all the co-variables with $p<20 \%$ simultaneously in Tables 2 or 3 in either gender;

** Model $\mathrm{A}=$ not controlled by age;

*** Model $B=$ controlled by age. 
Estimates from the multiple logistic regression model for sexual initiation, according to gender, for the final model * . Santiago Island, Cape Verde, 2007.

\begin{tabular}{|c|c|c|c|c|c|c|c|c|}
\hline \multirow[t]{4}{*}{ Independent variables } & \multicolumn{8}{|c|}{ Dependent variable: sexual initiation } \\
\hline & \multicolumn{4}{|c|}{ Model A ** } & \multicolumn{4}{|c|}{ Model B *** } \\
\hline & \multicolumn{2}{|c|}{ Female } & \multicolumn{2}{|c|}{ Male } & \multicolumn{2}{|c|}{ Female } & \multicolumn{2}{|c|}{ Male } \\
\hline & $\begin{array}{c}\text { OR } \\
(95 \% \mathrm{Cl})\end{array}$ & p-value & $\begin{array}{c}\text { OR } \\
(95 \% \mathrm{Cl})\end{array}$ & p-value & $\begin{array}{c}\text { OR } \\
(95 \% \mathrm{Cl})\end{array}$ & p-value & $\begin{array}{c}\text { OR } \\
(95 \% \mathrm{Cl})\end{array}$ & $p$-value \\
\hline \multicolumn{9}{|l|}{ Age bracket (years) } \\
\hline \multicolumn{9}{|l|}{$\leq 14$ (reference) } \\
\hline$>14$ & - & - & - & - & $\begin{array}{c}1.75 \\
(0.79 ; 3.87)\end{array}$ & 0.166 & $\begin{array}{c}2.32 \\
(1.15 ; 4.68)\end{array}$ & 0.019 \\
\hline \multicolumn{9}{|l|}{ Schooling (years) } \\
\hline \multicolumn{9}{|l|}{$\leq 9$ (reference) } \\
\hline$>9$ & $\begin{array}{c}3.00 \\
(1.81 ; 5.01)\end{array}$ & 0.000 & $\begin{array}{c}0.88 \\
(0.53 ; 1.44)\end{array}$ & 0.611 & $\begin{array}{c}2.25 \\
(1.19 ; 4.26)\end{array}$ & 0.012 & $\begin{array}{c}0.59 \\
(0.32 ; 1.09)\end{array}$ & 0.093 \\
\hline \multicolumn{9}{|l|}{ Partner } \\
\hline \multicolumn{9}{|l|}{ Without (reference) } \\
\hline With & $\begin{array}{c}3.33 \\
(1.93 ; 5.62)\end{array}$ & 0.000 & $\begin{array}{c}1.71 \\
(0.89 ; 3.31)\end{array}$ & 0.109 & $\begin{array}{c}3.21 \\
(1.90 ; 5.43)\end{array}$ & 0.000 & $\begin{array}{c}1.74 \\
(0.89 ; 3.39)\end{array}$ & 0.105 \\
\hline \multicolumn{9}{|l|}{ Religion } \\
\hline Catholic & $\begin{array}{c}0.85 \\
(0.24 ; 2.97)\end{array}$ & 0.801 & $\begin{array}{c}2.75 \\
(1.13 ; 6.73)\end{array}$ & 0.026 & $\begin{array}{c}0.81 \\
(0.23 ; 2.88)\end{array}$ & 0.744 & $\begin{array}{c}2.57 \\
(1.04 ; 6.35)\end{array}$ & 0.040 \\
\hline \multicolumn{9}{|l|}{ Others (reference) } \\
\hline \multicolumn{9}{|l|}{ Alcohol consumption } \\
\hline Yes & $\begin{array}{c}1.44 \\
(0.57 ; 3.63)\end{array}$ & 0.436 & $\begin{array}{c}2.57 \\
(1.11 ; 5.93)\end{array}$ & 0.027 & $\begin{array}{c}1.49 \\
(0.59 ; 3.78)\end{array}$ & 0.399 & $\begin{array}{c}2.48 \\
(1.07 ; 5.73)\end{array}$ & 0.034 \\
\hline No (reference) & & & & & & & & \\
\hline
\end{tabular}

OR: odds ratio; $95 \% \mathrm{Cl}$ : 95\% confidence interval.

${ }^{*}$ Exclusion of all the co-variables simultaneously with $p>5 \%$ in Table 4 in either gender;

** Model $A=$ not controlled by age;

*** Model $B=$ controlled by age.

more than $60 \%$ report that they do not wish to have children in their early years of marriage 20 . Although some female adolescents are anxious to conceive, most do not wish to have children early. Even among those that are married, approximately $66 \%$ in most of the countries wish to postpone motherhood. In addition to women's desire to bear children, many other factors determine whether they will use contraceptive methods: marital status, the family's expectations and community norms, and access to family planning and other health services 21 .

Use of contraceptive methods is also low in countries of North Africa and the Middle East, but varies considerably in Asia, where fewer than $5 \%$ of married adolescents in India and Pakistan use contraceptive methods, as compared to $40 \%$ in Indonesia and Thailand 21. With few exceptions, the countries of Latin America and the Ca- ribbean show higher rates of contraceptive use, varying from $30 \%$ to $53 \%$.

The high percentage of condom use by adolescents on Santiago Island, unlike that found in other studies, suggests that negotiation of male condom use has not been impeded by social standards based on unequal gender relations. This difference is relevant, because a study conducted in Brazil 2 indicates that negotiation of condom use encounters obstacles in social mores and disempowerment of women, who due to complicity, emotional insecurity, notions of romantic love, and fidelity may often fail to exert their reproductive power and their right to prevent themselves against STD/AIDS.

The low AIDS rate in Cape Verde is probably related to various factors: high prevalence of condom use; introduction of the sexual and reproductive education program in schools; free con- 
dom distribution; cooperative policies between Brazil and Portugal in the area of prevention; and treatment of sexually transmissible diseases, including HIV/AIDS 21.

In Cape Verde, the estimated HIV prevalence is low 22 (from $0.8 \%$ to $1.5 \%$ of the population), probably due to the high proportion of condom use as compared to other countries of Sub-Saharan Africa, where the epidemic appears to have stabilized, with a prevalence of $7.4 \% 16$. Still, the rate is worrisome from the public health perspective in Cape Verde.

In the current study, $12 \%$ of sexually active female adolescents reported a history of at least one pregnancy, a large share of whom at 16 years of age. Of those who had given birth in the previous 12 months, more than two-thirds (86\%) had done so at age 17 . These figures are similar to data from a study on teenage pregnancy in the capital city of Praia by the Organization of Cape Verdean Women 23 , in 1992, in which $46.4 \%$ of girls from 15 to 19 years of age reported a pregnancy before 19, with the largest share of pregnancies at age 17 . Some $90 \%$ of the pregnancies occur from 15 to 17 years, despite differences in the study population and the time transpired between the two studies. This may indicate the maintenance of some public policy effort in preventing pregnancy before 15 years of age.

The large number of Catholics in this study (84\%) corroborates the findings of other studies on the island with adolescents from 15 to 19 years of age, in 2000 and 2007 3,8 (in which $86 \%$ and $88.9 \%$ of the adolescents, respectively, stated that they were Catholic). It is interesting that condom use during sexual initiation is so prevalent in a predominantly Catholic country, since it contradicts official Catholic Church doctrine.

The current study found a positive association between Catholic religion and male sexual initiation. This may mean that Catholics are the ones that most value pleasure, and that this approaches valuing love as a gender meaning, according to a study of opinions and attitudes on sexuality in Brazil 24.

In the current study, more schooling was directly associated with sexual initiation in adolescents, thus contradicting the literature 21 , which has documented an association between lower schooling and earlier sexual initiation. It is possible that in Cape Verde, girls with more schooling feel safer in initiating their sexual activity, since they and their partners have more access to information and methods, leading to more protected sexual relations.

In the 1990s in Sub-Saharan Africa, particularly in Nigerian women 20 to 24 years of age and those who were married or in a stable union before 18 years of age, the proportion of sexually initiated individuals was higher among women with fewer than seven years of schooling (69\%) as compared to those with seven years or more (14\%). In Senegal, the proportion of sexually initiated women was also higher among those with fewer than seven years of schooling (54\%) as compared to those with seven years or more (6\%) 21.

A similar pattern is found in Latin America. In the 1990s in Brazil, the proportion of sexually initiated women was $34 \%$ among those with fewer than seven years of schooling and $14 \%$ among those with seven years or more. According to these studies, sexual initiation came earlier in women that were married or in a stable union before 18 years of age and that had less schooling 21 .

The effect of more schooling on sexual initiation in girls can be interpreted in terms of attitudes and personal projects, considering life choices and priorities, as described by other authors 16 . However, the association may have resulted either from the sample's characteristics, some random effect, or the island's peculiarities, since it differs from other studies and thus merits further study, given its importance for the theme at hand.

The variables religion, church attendance, media exposure, number of persons per household, age at menarche, and hometown were not associated with the target event (Table 4), in disagreement with other studies 5,16. Since young Cape-Verdeans live in a limited geographic space and constitute a relatively homogeneous population, they may not display large sociodemographic differences in terms of their habits 5,16 .

Meanwhile, in this study population, religion was only significantly associated with male gender (Tables 2 and 3).

Age at menarche, and particularly media exposure, have been identified as factors associated with sexual initiation 25 (earlier menarche associated with earlier sexual initiation). Various studies have shown menarche occurring at around 12 years of age 26,27 . In this study it occurred at 13.3 years, in other words later, but this was not associated with later sexual initiation.

Media exposure plays a significant role in promoting social changes in attitudes towards sexual and reproductive behavior, especially as a function of the type of information and programs that are broadcast and also due to linguistic homogeneity 2 . However, in the current study, contrary to expectations, media exposure did not prove relevant to the outcome (Tables 2, 3, and 4). 
As for alcoholic beverages, various studies have shown them to be the substances most widely sought by adolescents 28 . Furthermore, alcohol consumption has been associated with the occurrence of accidents and sexual behavior that leave them vulnerable to STDs and unplanned pregnancies 29 .

In this study, $10 \%$ of adolescents reported consuming alcohol (14\% of boys and $6 \%$ of girls). According to a study by the Zé Moniz Association for Society and Development 30 , alcohol is the most widely consumed substance, especially among boys.

This study's results also show that consumption of alcoholic beverages is positively associated with sexual initiation (Table 4). Given that this association was only observed in males, this may be viewed as a gender issue. This finding suggests that alcohol consumption may be related to modes of male socialization.

The current study shows different percentages of sexual initiation between male and female adolescents. Although this study corroborates the idea that sexual initiation in adolescents is occurring increasingly earlier, it runs counter to the notion that early sexual initiation usually occurs among adolescents that lack adequate information. The study population showed a significant level of information on the most well known forms of contraception (93\% knew some type of contraceptive method before they had their first sexual intercourse), and the majority knew that they should use condoms.
In comprising the study sample, there were no refusals or losses, thus guaranteeing its representativeness. Secondary students on Santiago Island represent $58 \%$ of the young people in this age bracket 11 .

Still, in studies like this, part of the differences between girls and boys may be due to reporting biases due to gender expectations, i.e., boys may over-report sexual experiences, while girls underreport them 31 .

This research shows that sexual initiation in adolescents can be safer if they have information, sex education, and access to methods.

The age variable proves to be important in the occurrence of the target event and should be considered when designing and implementing sexual and reproductive health promotion policies for adolescents. Still, such policies should not be applied only to sexually initiated adolescents, but also to those who are still sexually uninitiated, with the aim of fostering conditions for a sexual life that is more protected against unwanted pregnancies and STD/AIDS, free of coercion and violence, and with pleasure 7 . The current article thus provides food for thought on designing policies to reduce young people's vulnerability to STD/AIDS and particularly on the limits, possibilities, and challenges of strategies for the promotion of condom use and sex education that consider unequal gender relations and expand access to contraceptive methods, particularly targeting male adolescents. 


\section{Resumo}

Foram analisados fatores associados ao início da vida sexual de adolescentes na Ilha de Santiago, Cabo Verde, segundo sexo. Estudo realizado com amostra probabilística e representativa de 768 adolescentes, age 13-17 anos, de escolas secundárias públicas da Ilha de Santiago em 2007. A associação foi testada pelo teste de proporção, qui-quadrado de Pearson ou Fisher e regressão logística. Nos rapazes, os fatores associados ao início da vida sexual foram: idade maior que 14 anos, ser católico e consumo de bebidas alcoólicas. Para meninas: escolaridade maior que nove anos e ter parceiro afetivo-sexual. Ao contrário de outros contextos da África Subsaariana, foram constatadas taxas elevadas de uso de preservativo por adolescentes no início da vida sexual. Os adolescentes podem iniciar a vida sexual de maneira mais segura se tiverem informação, educação sexual e acesso a métodos de prevenção à gravidez $e$ às DST. Este artigo oferece elementos para a reflexão sobre o delineamento de políticas de redução da vulnerabilidade dos jovens às DST/AIDS e sobre os limites e desafios da promoção do uso do preservativo e educação sexual, focando as relações desiguais de gênero.

Saúde Sexual Reprodutiva; Preservativos; Adolescente

\section{Contributors}

C. M. Tavares and N. Schor worked on the design, writing, statistical data analysis, interpretation, and analysis of the article's results. S. G. Diniz and I. França Junior contributed to the interpretation of the results and writing of the article.

\section{Acknowledgments}

The authors wish to acknowledge the financial support from the Graduate Students Exchange Program (PEC-PG) under the Coordinating Body for Graduate Level Studies (CAPES). They also wish to thank Professor Cláudio Leone for contributing to the interpretation and analysis of the results.

\section{References}

1. Tavares CM. Fecundidade das mulheres caboverdianas em 1990 e 2000: evidências e interpretação [Masters Thesis]. Rio de Janeiro: Escola Nacional de Ciência e Estatística, Instituto Brasileiro de Geografia e Estatística; 2005.

2. Abramovay M, Castro MG, Lerena BS. Juventude e sexualidade. Brasília: Organização das Nações Unidas para a Educação, a Ciência e a Cultura; 2004.

3. Instituto Nacional de Estatística de Cabo Verde. Inquérito demográfico e de saúde reprodutiva 2005. Praia: Instituto Nacional de Estatística de Cabo Verde; 2007.

4. Bozon M. À quel âge les femmes et les hommes commencent-ils leur vie sexuelle? Comparaisons et évolutions récents. Popul Soc 2003; 391:1-4.

5. Leite IC, Rodrigues RN, Fonseca MC. Fatores associados com o comportamento sexual e reprodutivo entre adolescentes das regiões Sudeste e Nordeste do Brasil. Cad Saúde Pública 2004; 20:474-81.
6. Longo LAFB. Juventude e contracepção: um estudo dos fatores que influenciam o comportamento contraceptivo das jovens brasileiras de 15 a 24 anos. Revista Brasileira de Estudos Populacionais 2002; 19:229-47.

7. World Health Organization. Defining sexual health. Report of a technical consultation on sexual health. Geneva: World Health Organization; 2002. (WHO Sexual Health Document Series).

8. Instituto Nacional de Estatística de Cabo Verde/ Demographic and Health Surveys. Inquérito demográfico e de saúde reprodutiva 1998. Praia: Instituto Nacional de Estatística de Cabo Verde; 2000.

9. Instituto Nacional de Estatística de Cabo Verde. Censo demográfico 2000. Praia: Instituto Nacional de Estatística de Cabo Verde; 2002.

10. World Health Organization. Adolescent friendly health services - an agenda for change. Geneva: World Health Organization; 2002. 
11. Gabinete de Estudos e Planejamento, Ministério de Educação e Valorização de Recursos Humanos. Anuário estatístico. Cabo Verde: Ministério da Educação e Valorização de Recursos Humanos; 2003-2004.

12. Ministério da Saúde/Organização das Nações Unidas para a Educação, a Ciência e a Cultura. Criança e mulher em Cabo Verde: análise de situação. Praia: Ministério da Saúde/Organização das Nações Unidas para a Educação, a Ciência e a Cultura; 2002.

13. Paiva V, Calazans G, Venturi G, Dias R. Idade e uso de preservativo na iniciação sexual de adolescentes brasileiros. Rev Saúde Pública 2008; 42 Suppl 1: 45-53.

14. Borges ALV, Latorre MRDO, Schor N. Fatores associados ao início da vida sexual de adolescentes matriculados em uma unidade de saúde da família da zona leste do Município de São Paulo, Brasil. Cad Saúde Pública 2007; 23:1583-94.

15. Rua MG, Abramovay M. Avaliação das ações de prevenção às DST/AIDS e uso indevido de drogas nas escolas de ensino fundamental e médio em capitais brasileiras. Brasília: Organização das Nações Unidas para a Educação, a Ciência e a Cultura; 2001.

16. Bozon M, Heilborn ML. Iniciação à sexualidade: modos de socialização, interações de gênero e trajetórias individuais. In: Heilborn ML, Aquino EML, Bozon M, Knauth DR, organizadores. O aprendizado da sexualidade. Rio de Janeiro: Editora Garamond/Editora Fiocruz; 2006. p. 156-205.

17. Teixeira AMFB, Knauth DR, Fachel JMG, Leal AF. Adolescentes e uso de preservativos: as escolhas de jovens de três capitais brasileiras na iniciação e na última relação sexual. Cad Saúde Pública 2006; 22:1385-96.

18. Wellings K, Collumbien M, Slaymaker E, Singh S, Hodges Z, Patel D, et al. Sexual behaviour in context: a global perspective. Lancet 2006; 368: 1706-28.

19. Varela-Domingos AS. Programa de educação sexual em IST/HIV/SIDA com adolescentes de uma escola secundária de Cabo Verde: percepção dos atores envolvidos no programa [Masters Thesis]. Salvador: Instituto de Saúde Coletiva, Universidade Federal da Bahia; 2008.

20. Mott FL, Fondell MM, Hu PN, Kowaleski-Jones L, Menegham EG. The determinants of first sex by age 14 in a high-risk adolescent population. Fam Plann Perspect 1996; 28:13-8.
21. Guttmacher Institute. Rumo a um Novo Mundo: a vida sexual e reprodutiva de mulheres jovens. http://www.guttmacher.org/pubs/new_world port.html (accessed on 29/Feb/2008).

22. Comitê de Coordenação de Combate à Sida/Programa das Nações Unidas para o Desenvolvimento. Estudo qualitativo e estimativa do tamanho de duas populações em risco para o VIH/SIDA: usuários de drogas injetáveis e profissionais de sexo. Praia: Comitê de Coordenação de Combate à Sida/ Programa das Nações Unidas para o Desenvolvimento; 2006.

23. Organização das Mulheres de Cabo Verde. Relatório do inquérito sobre a gravidez precoce na Praia. Praia: Organização das Mulheres de Cabo Verde: 1992.

24. Paiva V, Aranha F, Bastos F. Opiniões e atitudes em relação à sexualidade: pesquisa de âmbito nacional, Brasil 2005. Rev Saúde Pública 2008; 42 Suppl 1: 54-64.

25. Organização das Nações Unidas para a Educação, a Ciência e a Cultura. AIDS - epidemia. Geneva: Programa Conjunto das Nações Unidas sobre HIV/ AIDS; 2004.

26. Ministério da Saúde/Federação Brasileira das Sociedades de Ginecologia e Obstetrícia. Material instrucional de capacitação para a assistência em planejamento familiar. Módulo 4. http:/ /www.ucg. $\mathrm{br} /$ site_docente/enf/luciene/pdf/saude/MoDU LO4.pdf (accessed on 07/Aug/2007).

27. Ministério da Saúde/Federação Brasileira das Sociedades de Ginecologia e Obstetrícia/Comissão Nacional Especializada do Planejamento Familiar. Manual de orientação de anticoncepção. http:// www.gosites.com.br/sggo/pdf.asp?path=302553jh \%7Cggeyny7zmls2rjl4\&arq=rcq\%7Chp678892vml (accessed on 07/Dec/2007).

28. Gupta N, Leite IC. Tendências e determinantes da fecundidade entre adolescentes no Nordeste do Brasil. Perspectivas Internacionais de Planejamento Familiar 2001; número especial:24-9.

29. Aarons G, Brown S, Coe M, Myers M, Garland A, Ezzet-Lofstram, et al. Adolescent alcohol and drug abuse and health. J Adolesc Health 1999; 24:412-21.

30. Associação para a Sociedade e Desenvolvimento Zé Moniz. A saúde e o estilo de vida dos adolescentes cabo-verdianos, freqüentando o ensino secundário. Praia: Associação para a Sociedade e Desenvolvimento Zé Moniz; 2005.

31. Narring F, Wydler H, Michaud PA. First sexual intercourse and contraception: a cross-sectional survey on the sexuality of 16-20-year-olds in Switzerland. Schweiz Med Wochenschr 2000; 130:1389-98.

Submitted on 12/May/2008

Final version resubmitted on $10 / \mathrm{Sep} / 2008$

Approved on 24/Oct/2008 